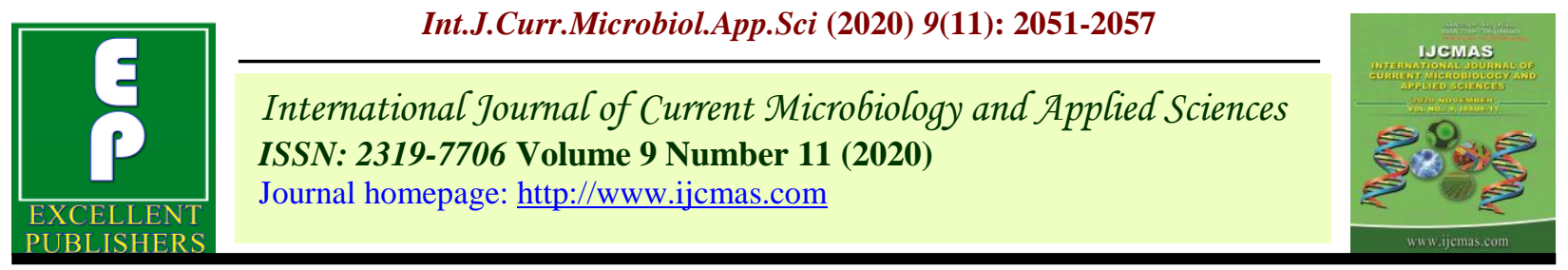

Original Research Article

https://doi.org/10.20546/ijcmas.2020.911.244

\title{
Effect of Seed Priming and Foliar Spray of Bio-regulators on Yield and Yield Attributes of Chickpea (Cicer arietinum L.) under Conserved Moisture Condition
}

\author{
R. N. Choudhary ${ }^{1^{*}}$, K. J. Suthar ${ }^{1}$ and N. J. Patel ${ }^{2}$ \\ ${ }^{1}$ Agricultural Research Station, Anand Agricultural University, Dhandhuka, Gujarat, India \\ ${ }^{2}$ Department of Biochemistry, $A A U$, Anand, India \\ *Corresponding author
}

\section{A B S T R A C T}

\begin{tabular}{|l|}
\hline Ke y w or d s \\
Chickpea, \\
Seed priming, \\
Foliar spray, \\
Thiourea, TGA
\end{tabular}

A three year field experiment was conducted in rabi seasons during 2014 to 2016 under conserved moisture condition aims of the experiment to find out the suitable bio- regulator and its effect on chickpea (Cicer arietinum L.), experiment treatments were applied as seed soaking with thiourea $(500 \mathrm{ppm})$, salicylic acid $(50 \mathrm{ppm})$, thioglycolic acid (50 ppm (before sowing) and foliar spray of water, thiourea $(1000 \mathrm{ppm})$, salicylic acid (100 ppm) thioglycolic acid (100 ppm) at vegetative stage and flowering stage and one is absolute control in both of factors. Among the treatments imposed, significantly higher seed yield (1759, 1314, 1284 $\mathrm{kg} \mathrm{ha.)}$ recorded with soaking with thiourea $(500 \mathrm{ppm})$ and foliar spray (1897, $1362,1337 \mathrm{~kg}$ ha. $)$ of thiourea $(1000 \mathrm{ppm})$ over control in all individual three years.

\section{Introduction}

Chickpea (Cicer arietinum L.) is approximately $90 \%$ of worlds grown in the arid and semi-arid zones under rainfed conditions (Kumar and Abbo, 2001) and fourth most important grain legume with a total global production of 13.1 million ton from $13.5 \mathrm{~m}$ ha area \& India is the largest producer and consumer of chickpea contributing to $70 \%$ of world's total production (Vineeth. et al., 2017). In India drought is the most limiting factor in production in semi -arid ecosystem of
Gujarat. Primarily the failure, prolonged dry spells and erratic behavior of south - west monsoon are the major cause of drought. There is a growing demand for chickpea due to its nutritional value. It is rich source of protein contain about $17-20 \%$. In the semiarid tropics chickpea is an important component of the diets of those individuals who cannot afford animal proteins or those who are vegetarian by choice. Chickpea is a good source of carbohydrates and protein and cholesterol free. It is also good source of dietary fiber, vitamins and minerals (Maurya et al., 2018) Abiotic stresses such as drought, 
salinity, high temperature, low temperature adversely affect plant growth and agricultural productivity. Amongst the various abiotic stresses, drought is the most devastating stress limiting crop production and yield particularly in arid and semi-arid regions (Araujo et al., 2015). It influenced various physiological and biochemical processes, such as translocation, ion uptake, respiration, photosynthesis, carbohydrates, nutrient metabolism and hormones (Farooq et al., 2009), and ended with plant general growth retardations leading to death. In recent years, use of bio-regulators like thiourea, salicylic acid (SA) and thioglycolic acid (TGA) has offered new avenues for enhancing productivity of several crops through stress migration. They influence a wide array of physiological parameters like alteration of plant architecture, assimilate partitioning, promotion of photosynthesis, uptake of nutrients (mineral ions), enhancing nitrogen metabolism, increased mobilization of assimilates to defined sinks, induction of synchrony in flowering, and delayed senescence of leaves (Sharma et al., 2013) among the bio- regulator, thiourea proved most efficient because it content nitrogen and sulfur containing compound with better water solubility and absorption potential is known to impart tolerance against prevailing abiotic stresses. Structurally, its molecule has two main functional groups; 'thiol' is reported vital for oxidative stress response and 'imino' strikingly capable to fulfill the increased $\mathrm{N}$ requirement under abiotic stress conditions. Thiols are well-known to maintain the disturbed redox state (-SH/-S-S- ratio) of the cell and its proper functioning under stress conditions (Nathawat et al., 2007 and Dhikwal et al., 2012).

\section{Materials and Methods}

The experiment was conducted rabi session 2014 to 2016 for three years at Agricultural
Research Station, Anand Agricultural University, Dhandhuka, Gujarat. The soil of the experiment field is medium black clay loamy with $\mathrm{pH} 8.7$ and medium rang in available in nitrogen (215 kg/ha), low in available phosphorus $(5.46 \mathrm{~kg} / \mathrm{ha})$ and high in available potassium $(475 \mathrm{~kg} / \mathrm{ha})$ with $0.46 \%$ organic carbon. The total rainfall received during the crop seasons (June to September) was 1050, 715 and $541 \mathrm{~mm}$, respectively. The average rain fall of station is $625 \mathrm{~mm}$. The experiment was laid out in randomization block design (Factorial) with 20 treatment combinations of seed priming $\left(\mathrm{S}_{0}\right.$-No seed soaking, $\mathrm{S}_{1}$-seed soaking with thiourea (500 ppm), $S_{2}$ - seed soaking with salicylic acid (50 $\mathrm{ppm}), \mathrm{S}_{3}$ - seed soaking with thioglycolic acid (50 ppm) for one hour before sowing and foliar spray $\left(\mathrm{C}_{0}\right.$ - No spray (Control), $\mathrm{C}_{1}$-water spray, $\mathrm{C}_{2}$-thiourea spray $(1000 \mathrm{ppm}), \mathrm{C}_{3^{-}}$ salicylic acid spray $(100 \mathrm{ppm}), \mathrm{C}_{4^{-}}$ thioglycolic acid spray (100 ppm) with three replications. The chickpea variety GG-2 was sown at $30 \mathrm{~cm}$ spacing in conserved moisture which is received during month of June and September for respective years and no supplemental irrigation given to crop during the seasons and two foliar sprays of bioregulators were applied at vegetative and flowering stage of crop. The maximum and minimum temperature fluctuate between 45.5 ${ }^{0} \mathrm{C}$ to $8.2{ }^{0} \mathrm{C}$. The observation on plant stand/m plant height $/ \mathrm{cm}$ taken at different stages \& for bio-chemical analysis leaf sample was taken after 10 days of each spray whereas, test weight (g) and seed yield $\left(\mathrm{kg} \mathrm{ha}^{-1}\right)$ were recorded after harvest. The data from various characters under study were analyzed by the statistics department of Anand Agricultural University- Anand.

\section{Results and Discussion}

The seed priming and foliar spray of bioregulators significantly influence on the yield \& yield attributes (plant height, no of 
branches, pods per plant, test weight and seed $\&$ biological yield) of rainfed chickpea under conserved moisture condition and data was presented on pooled basis (Table $1 \& 2$ ).

\section{Yield attributes}

Seed priming: Seed priming play an impotent role under conserved moisture condition and significantly influence the yield and yield parameters of chickpea over control. Seed priming with thiourea @ 500 ppm $\left(S_{1}\right)$ recorded significantly higher plant population (8.13) per meter over control (7.27) and found at par with TGA @ 50 ppm $\left(\mathrm{S}^{3}\right)$ (7.99). In addition to breaking innate dormancy (ElKeblawy and Gairola, 2017), the seed treatment with thiourea accelerates the seed germination in non-dormant seeds. The data showed in Table 1 for plant height indicate that significantly higher data was recorded with thiourea@ 500 ppm $\left(\mathrm{S}_{1}\right)$ in the tune of $48.47 \mathrm{~cm}$ over control (45.58) while found at par with TGA @ $50 \mathrm{ppm}\left(\mathrm{S}_{3}\right)$. The thiourea with its sulphydryl group regulates several metabolic reactions in the plant both under normal as well as stress conditions. Under stress conditions it acts as an antioxidant by protecting primary photochemical reactions of photosystem 1 and photosystem 2 and enhances the activities of antioxidant enzymes (Nathawat et al., 2007). Seed priming with thiourea@ 500 ppm $\left(\mathrm{S}_{1}\right)$ gave superior results in case of number of branches per plant, number of pods per plant, number of seed per pod and test weight (g) which is 7.68, 76.05, 1.11 and 34.11 respectively, over (7.10, $70.31,1.03 \& 32.50)$ control. Number of branches (7.64) and seed per pod (1.08) found at par with TGA seed priming @ 50 ppm $\left(\mathrm{S}_{3}\right)$ while number of pods per plant (74.87) and test weight (33.41) at par with SA seed priming @ 50 ppm $\left(\mathrm{S}_{2}\right)$. The thiourea application might have favoured the greater translocation of assimilates from source to sink for longer period in comparison to control treatment which lead to effective grain filling. Sahu et al., (1993) and Shanu et al., (2013) also reported improvement yield attributes of coriander with seed priming and foliar spray of thiourea. Presoaking sowing process elevates the negative effect of drought and makes active in metabolic process (Murad et al., 2016)

Chemical spray: A great number of studies provide evidence regarding role of foliar spray applied thiourea in modulating physiological mechanisms and improve final yield. Foliar spray of thiourea @1000 ppm $\left(\mathrm{C}_{2}\right)$ significantly improve yield and yield attributes (Table 1). Due to foliar spray of thiourea@1000 ppm $\left(\mathrm{C}_{2}\right)$ plant stand per meter row (8.41), plant height/cm (48.68), number of branches per plant (7.94), number of pods per plant (77.96), number of seed per pod (1.16) and test weight/g (34.25) influence significantly over control, 7.53, 45.56, 6.99, $70.87,1.04 \& 32.45$ respectively, on pooled basis of three years and found at par with $\mathrm{C}_{3}$ treatment (SA spray $(100 \mathrm{ppm})$ in case of plant stand per meter row (7.83), number of branches per plant (7.47), number of pods per plant (73.80), number of seed per pod (1.07) and test weight/g (33.50) whereas plant height $/ \mathrm{cm}$ (47.96) found at par with $\mathrm{C}_{4}$ treatment (TGA spray (100 ppm).

Foliar spray of $5 \mathrm{mM}$ thiourea improved the photo-system activity along with the expression of antioxidant (both enzymatic and non-enzymatic system) (Hassanein et al., 2015). Previous studies confirm that thiourea increased the plant growth under salt stress condition, which might be due to increase in antioxidant activities that alleviated the stress damage (Francisco et al., 2008 \& Perveen et al., 2015).

Interaction effect: Seed priming and foliar spray of stress mitigating bio-regulators interaction effect was found non significant in 
all yield parameters in individual years and in pooled analysis (Table 1).

\section{Yield \& B: C ratio}

Seed priming: Perusal of data presented in Table 2 reveled that effect of different seed priming treatment on seed protein was found significant and higher data were recorded with $\mathrm{S}_{1}$ treatment (Thiourea @ 500 ppm) $(17.83 \%)$ over control $\mathrm{S}_{0}(17.33 \%)$ in pooled analysis of three years while data found at par with $\mathrm{S}_{3}$ treatment $(17.79 \%)$. Due to application of SH- compounds had significant influence on protein yield of grains confirmed by Meena and Sharma (2005). Thiourea also plays favourable role to increase soluble protein and free amino acids (Garg et al., 2006) and thiols been found to enhance the translocation of sucrose from source to sink. Among the various seed priming treatment significantly higher seed yield $\mathrm{kg} / \mathrm{ha}$ was recorded with $\mathrm{S}_{1}$ treatment (Thiourea @ 500 $\mathrm{ppm}$ ) and magnitude data is $1452 \mathrm{~kg} / \mathrm{ha}$ in comparison to the lowest (1305 kg/ha) recorded with control which remained at par with $\mathrm{S}_{2}$ treatment (SA @ 50 ppm) (1386 $\mathrm{kg} / \mathrm{ha}$ ). Treatment $\mathrm{S}_{3}$ (TGA @ $50 \mathrm{ppm}$ ) rank third in performance (1371 kg/ha) but it remained at par with $S_{2}$ treatment (SA @ 50 ppm) (1386 kg/ha) and significantly higher over control on basis of three year pooled analysis. Same trend was found in biological yield of chickpea and appreciably data associated with $S_{1}$ treatment (Thiourea @ 500 ppm) which is $2192 \mathrm{~kg} / \mathrm{ha}$ over control (1987 $\mathrm{kg} / \mathrm{ha}$ ) and remained at par with $\mathrm{S}_{3}$ treatment (TGA @ 50 ppm) $(2165 \mathrm{~kg} / \mathrm{ha})$ on basis of three year pooled analysis. Thiourea with its sulfhydral group not only favoured larger green photosynthetic surface but it might have also favoured the activity of starch synthetase and hence the effective period of filling seeds (Shanu at el., 2013) and ultimately yield is increase. Higher B:C ratio (2.59) was recorded with $S_{1}$ treatment (Thiourea @ 500 ppm) in comparison to control (2.27).

Table.1 Effect of seed priming and foliar spray of stress mitigating chemical on yield attributes of rainfed chickpea under conserved moisture condition

\begin{tabular}{|c|c|c|c|c|c|c|}
\hline \multirow[t]{2}{*}{ Treatment } & \multicolumn{6}{|c|}{ Yield attributes of chickpea } \\
\hline & $\begin{array}{c}\text { Plant } \\
\text { Stand } / \mathbf{m}\end{array}$ & $\begin{array}{c}\text { plant } \\
\text { height } / \mathrm{cm}\end{array}$ & $\begin{array}{c}\text { No of } \\
\text { branches /plant }\end{array}$ & $\begin{array}{c}\text { No of } \\
\text { pods/plant }\end{array}$ & $\begin{array}{c}\text { No of } \\
\text { seeds/plant }\end{array}$ & $\begin{array}{c}\text { Test } \\
\text { weight/g }\end{array}$ \\
\hline \multicolumn{7}{|l|}{ (A) Seed Priming } \\
\hline$S_{0}:$ Control & 7.27 & 45.58 & 7.10 & 70.31 & 1.03 & 32.50 \\
\hline $\begin{array}{l}S_{1}: \text { Thiourea priming (500 } \\
\text { ppm) }\end{array}$ & 8.13 & 48.47 & 7.68 & 76.05 & 1.11 & 34.14 \\
\hline $\mathrm{S}_{2}:$ SA priming (50ppm) & 7.81 & 47.23 & 7.32 & 74.87 & 1.07 & 33.41 \\
\hline$S_{3}:$ TGA priming (50ppm) & 7.99 & 47.52 & 7.64 & 74.85 & 1.08 & 33.40 \\
\hline $\operatorname{Sem} \pm$ & 0.12 & 0.37 & 0.12 & 0.62 & 0.01 & 0.27 \\
\hline CD@5\% & 0.34 & 1.05 & 0.33 & 1.77 & 0.04 & 0.77 \\
\hline \multicolumn{7}{|l|}{ (B) Chemical Spray } \\
\hline $\mathrm{C}_{0}:$ Control & 7.53 & 45.56 & 6.99 & 70.87 & 1.04 & 32.45 \\
\hline$C_{1}$ : Water spray & 7.48 & 47.04 & 7.42 & 73.86 & 1.04 & 33.14 \\
\hline$C_{2}$ : Thiourea spray (1000 ppm) & 8.41 & 48.68 & 7.94 & 77.96 & 1.16 & 34.25 \\
\hline $\mathrm{C}_{3}$ : SA spray (100ppm) & 7.83 & 46.75 & 7.47 & 73.80 & 1.07 & 33.50 \\
\hline $\mathrm{C}_{4}:$ TGA spray (100ppm) & 7.77 & 47.96 & 7.37 & 73.62 & 1.05 & 33.48 \\
\hline $\operatorname{Sem} \pm$ & 0.13 & 0.41 & 0.13 & 0.69 & 0.02 & 0.30 \\
\hline CD@ $5 \%$ & 0.39 & 1.19 & 0.38 & 2.00 & 0.05 & 0.87 \\
\hline $\mathrm{S} \times \mathrm{C}$ & NS & NS & NS & NS & NS & NS \\
\hline CV\% & 5.93 & 3.02 & 6.06 & 3.24 & 5.14 & 3.11 \\
\hline
\end{tabular}


Table.2 Effect of seed priming and foliar spray of stress mitigating chemical on protein, yield, and economics of rainfed chickpea under conserved moisture condition

\begin{tabular}{|c|c|c|c|c|}
\hline Treatment & $\begin{array}{c}\text { Seeds } \\
\text { protein }(\%)\end{array}$ & $\begin{array}{c}\text { Seed } \\
\text { yield (kg/ha) }\end{array}$ & $\begin{array}{c}\text { Biological } \\
\text { yield (kg/ha) }\end{array}$ & B:C ratio \\
\hline \multicolumn{5}{|l|}{ (A) Seed Priming } \\
\hline$S_{0}:$ Control & 17.33 & 1305 & 1987 & 2.27 \\
\hline$S_{1}$ : Thiourea priming (500 ppm) & 17.83 & 1452 & 2192 & 2.59 \\
\hline $\mathrm{S}_{2}: \mathrm{SA}$ priming (50ppm) & 17.72 & 1386 & 2152 & 2.45 \\
\hline$S_{3}:$ TGA priming (50ppm) & 17.79 & 1371 & 2165 & 2.42 \\
\hline Sem \pm & 0.12 & 20.23 & 30.55 & - \\
\hline CD@5\% & 0.35 & 57.91 & 87.45 & - \\
\hline \multicolumn{5}{|l|}{ (B) Chemical Spray } \\
\hline $\mathrm{C}_{0}:$ Control & 17.64 & 1275 & 2001 & 2.21 \\
\hline$C_{1}:$ Water spray & 17.45 & 1317 & 2082 & 2.23 \\
\hline $\mathrm{C}_{2}$ : Thiourea spray $(1000 \mathrm{ppm})$ & 17.92 & 1532 & 2226 & 2.67 \\
\hline $\mathrm{C}_{3}:$ SA spray (100ppm) & 17.50 & 1392 & 2138 & 2.36 \\
\hline$C_{4}:$ TGA spray (100ppm) & 17.83 & 1375 & 2173 & 2.35 \\
\hline $\operatorname{Sem} \pm$ & 0.14 & 22.62 & 34.15 & - \\
\hline CD@ 5\% & NS & 65.31 & 98.62 & - \\
\hline $\mathrm{S} \times \mathrm{C}$ & Sig & NS & Sig & - \\
\hline CV\% & 2.65 & 5.68 & 5.57 & - \\
\hline
\end{tabular}

Table.3 Interaction of seed priming and foliar spray of stress mitigating chemicals on seed protein $(\%)$ of rainfed chickpea in pooled analysis

\begin{tabular}{|l|c|c|c|c|c|}
\hline \multirow{2}{*}{ Chemical spray } & \multicolumn{3}{|c|}{ Seed priming } \\
\cline { 2 - 6 } & $\mathrm{S}_{0}$ & $\mathrm{~S}_{1}$ & $\mathrm{~S}_{2}$ & $\mathrm{~S}_{3}$ & Mean \\
\hline $\mathbf{C}_{\mathbf{0}}$ & 16.66 & 17.89 & 18.19 & 17.83 & 17.64 \\
\hline $\mathbf{C}_{\mathbf{1}}$ & 17.20 & 17.35 & 17.62 & 17.63 & 17.45 \\
\hline $\mathbf{C}_{\mathbf{2}}$ & 18.10 & $\mathbf{1 8 . 7 2}$ & 17.18 & 17.69 & 17.92 \\
\hline $\mathbf{C}_{\mathbf{3}}$ & 17.25 & 17.80 & 16.99 & 17.96 & 17.50 \\
\hline $\mathbf{C}_{\mathbf{4}}$ & 17.47 & 17.40 & 18.60 & 17.86 & 17.83 \\
\hline Mean & 17.33 & 17.83 & 17.72 & 17.79 & \\
\hline Sem \pm & 0.27 & & & & \\
\hline C D @ 5\% & 0.78 & & & & \\
\hline CV\% & 2.65 & & & & \\
\hline
\end{tabular}

Table.4 Interactive effect of seed priming and foliar spray of stress mitigating chemicals on biological yield $(\mathrm{kg} / \mathrm{ha})$ of rainfed chickpea in pooled analysis

\begin{tabular}{|l|c|c|c|c|c|}
\hline \multirow{2}{*}{\begin{tabular}{c}
\multirow{2}{*}{$\begin{array}{c}\text { Chemical } \\
\text { Spray }\end{array}$} \\
\cline { 2 - 6 }
\end{tabular}} & $\mathrm{S}_{0}$ & $\mathrm{~S}_{1}$ & $\mathrm{~S}_{2}$ & $\mathrm{~S}_{3}$ & Mean \\
\hline $\mathbf{C}_{\mathbf{0}}$ & 1701 & 2056 & 2161 & 2088 & 2002 \\
\hline $\mathbf{C}_{\mathbf{1}}$ & 1892 & 2165 & 2133 & 2139 & 2082 \\
\hline $\mathbf{C}_{\mathbf{2}}$ & 2058 & $\mathbf{2 3 3 3}$ & 2138 & 2375 & 2226 \\
\hline $\mathbf{C}_{\mathbf{3}}$ & 2120 & 2117 & 2169 & 2148 & 2139 \\
\hline $\mathbf{C}_{\mathbf{4}}$ & 2166 & 2289 & 2161 & 2078 & 2174 \\
\hline Mean & 1987 & 2192 & 2153 & 2166 & \\
\hline Sem \pm & 68 & & & & \\
\hline C D @ 5\% & 197 & & & & \\
\hline CV\% & 5.57 & & & & \\
\hline
\end{tabular}


Chemical spray: A perusal of data presented in Table 2 regarding spray of stress mitigating bio-regulators reveled that significantly higher data recorded in regarding seed protein with $\mathrm{C}_{2}$ treatment (Thiourea @ 1000 ppm) (17.92\%) over control $\mathrm{C}_{0}(17.64 \%)$ on basis of three year pooled analysis and remain at par with $\mathrm{C}_{4}$ treatment (TGA @ 100 ppm). A significant higher data seed and biological yield was recorded with $\mathrm{C}_{2}$ treatment (Thiourea @ 1000 ppm) is 1532 \& 2226 $\mathrm{kg} / \mathrm{ha}$ over control $\left(\mathrm{C}_{0}\right)$ is $1257 \& 2001 \mathrm{~kg} / \mathrm{ha}$ respectively, whereas second and third position occupied by $\mathrm{C}_{3}(1392 \mathrm{~kg} / \mathrm{ha}) \& \mathrm{C}_{4}$ $(1375 \mathrm{~kg} / \mathrm{ha})$ treatment in case of seed yield while in biological yield second and third position occupied by $\mathrm{C}_{4}(2173 \mathrm{~kg} / \mathrm{ha}) \& \mathrm{C}_{3}$ $(2138 \mathrm{~kg} / \mathrm{ha})$ treatment, respectively. These result closely confirmed by Abhishek at el. (2019) accordion to foliar spray of thiourea @ 1000 ppm apply to chickpea crop gave significantly higher yield as compare to control. Ample support to such effects in maize due to foliar spray of thiourea @ 1000 ppm was also reported by Sahu et al., (1993). In response of $\mathrm{B}: \mathrm{C}$ ratio the higher data originate with $\mathrm{C}_{2}$ treatment(2.67) (Thiourea @ $1000 \mathrm{ppm})$ in comparison to control (2.21).

Interaction Effect: Seed priming (S) and foliar spray (C) of stress mitigating bioregulators interaction effect was found significant (Table 3 and 4) in case of seed protein and biological yield on the pooled analysis basis and combination found is $\mathrm{S}_{1} \mathrm{C}_{2}$ whereas, in case of seed yield it is found non significant (Table 2).

Based on present study, it was concluded that that thiourea application has significant influence on chickpea productivity. Seed priming of chickpea seeds in @ 500 ppm thiourea and its sprays (1000 ppm) one at vegetative and one at flowering stage resulted in good productivity of chickpea and was most remunerative as compared with the other treatments and control. This could have the utility against different stresses and offered as a solution to the problem faced with drought stress.

\section{References}

Abhishek, S.R., Doddagoudar, Basavegowda, Shakuntala, N.M., Meena, M.K. (2019). Mitigation of Moisture Stress through Foliar Spray of Thiourea, Salicylic Acid and Homobrassinolide in Chickpea (Cicer arietinum L.). Legume research 10.18805 / LR - 4206 (1-6).

Araujo, S.S., Beebe, S., Crespi, M., Delbred, B., Gonzalez, E.M., Gruber, V., Lejeune-Henaut, I., et al., (2015). Abiotic stress responses in legumes: strategies used to cope with environmental challenges. Critical Review of Plant Science, 34: 237-280.

Dhikwal, S.R., Kumawat, S.M., Das, S and Jat, B.L. (2012). Effect of bio-regulators application on productivity of barley quality of pigeon pea [Cajanus cajan (L.)]. Legume Res., 33(4):263-268.

El-Keblawy, A. and Gairola, S. (2017). Dormancy regulating chemicals alleviate innate seed dormancy and promote germination of desert annuals. J. Plant Growth Regul., 36: 300-311

Farooq M, Wahid A, Kobayashi N, Fujita D, Basra S. M. A. (2009). Plant drought stress: effects, mechanisms and management. Agron. Sustain. De. 29: 185-21.

Francisco, A. A., A.R. Tavares, S. Kanashiro, P.R.R. Ramos and G.P.P. Lima (2008). Plant growth regulators in polyamines endogenous levels during the development of taro cultivated in vitro. Ciencia Rural, 38: 1251-1257

Garg, B. K., Burman, U. and Kathju, S. (2006). Influence of thiourea on photosynthesis, nitrogen metabolism amd yield of clusterbean under rainfed 
conditions of Indian arid zone. Plant Growth Regulation. 48: 237-245.

Hassanein, R.A., A.A. El-Said Amin, E.M. Rashad and H. Ali (2015). Effect of thiourea and salicylic acid on antioxidant defense of wheat plants under drought stress. Int. J. Chem. Tech. Res., 7: 346-354

Kumar, J. and Abbo, S. (2001). Genetics of flowering time in chickpea and its bearing on productivity in semi-arid environments. Adv. Agron. 72: 107-138.

Maurya, Omprakash and Kumar, Hemant (2018). Growth of chickpea production in India. Journal of Pharmacognosy and Phytochemistry 2018; 7(5): 1175-1177

Meena, B. S. and Sharma, D.D. (2005). Effect of phosphorus sources, solublizers and bio-regulators on growth, yield and phosphorus uptake by pigeonpea (Cajanus cajan). Indian Journal of Agronomy. 50 (2): 143-145.

Murad Ali, Zia Ullah, Ishaq Ahmad Mian, Naseem Khan, Nangialkhan, Muhammad Adnan (2016). Response of maize to nitrogen levels and seed priming. Pure and Applied Biology.; 5:578-587

Nathawat, N. S., Nair, J. S., Kumawat, S. M., Yadava, N. S., Singh, G., Ramaswamy, N. K., Saha, M. P. and D'Souza, S. F. (2007). Effect of seed soaking with thiols on the antioxidant enzymes and photosystem activities in wheat subjected to water stress. Biol.
Plantarum. 51(1): 93-97.

Perveen A. A., Wahid, S. Mahmood, I. Hussain and R. Rasheed (2015). Possible mechanism of root-applied thiourea in improving growth, gas exchange and photosynthetic pigments in cadmium stressed maize (Zea mays). Braz. J. Bot., 38: 71-79

Sahu, M. P., Solanki, N. S. and Dashora, L. N. (1993). Effect of thiourea, thiamin and ascorbic acid on growth and yield of maize (Zea mays L.).J. Agron. Crop Sci. 171: 65-69.

Shanu, Naruka, I. S., Singh, P. P., Shaktawat, R. P. S. and Verma, K. S. (2013). Effect of seed treatment and foliar spray of thiourea on growth, yield and quality of coriander (Coriandrumsativum L.) under different irrigation levels. International J. Seed Spices. 3(1):2025.

Sharma, P., Sardana, V., and Sukhvinder Singh, K. (2013). Dry matter partitioning and source-sink relationship as influenced by foliar sprays in groundnut. The Bioscan, 8; 1171-1176.

Vineeth T.V., Kumar Pramod and Singh Jasvir (2017). Bioregulators protected the leaf anatomy and photosynthetic machinery under water deficit stress in chickpea (Cicer arietinum L.) Legume Research, 40 (2) 2017: 250-256

\section{How to cite this article:}

Choudhary, R. N., K. J. Suthar and Patel, N. J. 2020. Effect of Seed Priming and Foliar Spray of Bio-regulators on Yield \& Yield Attributes of Chickpea (Cicer arietinum L.) under Conserved Moisture Condition. Int.J.Curr.Microbiol.App.Sci. 9(11): 2051-2057. doi: https://doi.org/10.20546/ijcmas.2020.911.244 